\title{
Draft genome sequences for the obligate bacterial predators Bacteriovorax spp. of four phylogenetic clusters
}

\author{
Huan Chen ${ }^{1,2}$, Lauren M Brinkac ${ }^{3}$, Pamela Mishra ${ }^{3}$, Nan Li', Despoina S Lymperopoulou', Tamar L Dickerson ${ }^{1}$, \\ Nadine Gordon-Bradley ${ }^{1}$, Henry N Williams ${ }^{1}$ and Jonathan $\mathrm{H} \mathrm{Badger}^{4^{*}}$
}

\begin{abstract}
Bacteriovorax is the halophilic genus of the obligate bacterial predators, Bdellovibrio and like organisms. The predators are known for their unique biphasic life style in which they search for and attack their prey in the free living phase; penetrate, grow, multiply and lyse the prey in the intraperiplasmic phase. Bacteriovorax isolates representing four phylogenetic clusters were selected for genomic sequencing. Only one type strain genome has been published so far from the genus Bacteriovorax. We report the genomes from non-type strains isolated from aquatic environments. Here we describe and compare the genomic features of the four strains, together with the classification and annotation.
\end{abstract}

Keywords: Predatory bacteria, Bdellovibrio and like organisms, Bacteriovorax, Marine, Gram-negative, Motile

\section{Introduction}

As a member of the highly diverse Deltaproteobacteria class, the obligate bacterial predators Bdellovibrio and like organisms possess unique ecological features that are worth exploring. They are the only known predatory bacteria that exhibit a life cycle alternating between an extracellular free-living phase and an intraperiplasmic phase and are capable of invading the periplasmic space of prey cells, resulting in the lysis of the prey and release of new progeny [1]. Based on their small size, about 1/ 5th that of a typical bacterium cell, BALOs have been called "the world's smallest hunters". Nevertheless, their genomes are larger than expected, more than $3.98 \mathrm{Mb}$ in Bdellovibrio. bacteriovorus Tiberius [2], 3.78 $\mathrm{Mb}$ in $B$. bacteriovorus HD100 [1] and 3.44 Mb in Bacteriovorax marinus SJ [3]. Despite the uniqueness [4], and increasing understanding, of the potential of these organisms in various applications [5-7], their phylogeny and unique predatory features are only beginning to be understood.

Systematics has played a most important role in advancing the study of the BALOs. Based on systematic genomic molecular techniques, the original BALO genus,

\footnotetext{
* Correspondence: jhbadger@gmail.com

4J Craig Venter Institute, La Jolla, CA 92037, USA

Full list of author information is available at the end of the article
}

Bdellovibrio, has been subdivided into four genera: Bdellovibrio, Bacteriolyticum, Peredibacter, and Bacteriovorax [8-10]. Being an exclusive saltwater genus, Bacteriovorax is distinct from the freshwater/terrestrial members of BALOs in many ways. It is ubiquitous in salt-water environments [10], requires at least $0.5 \% \mathrm{NaCl}$ for growth, prefers saltwater prey [11], thrive at a lower temperature range [12] and has a lower \% GC ratio of ca. 37\% [13] compared to the $50.65 \%$ of the freshwater Bdellovibrio bacteriovorus HD100. Currently, Bacteriovorax marinus $\mathrm{SJ}$ is the only strain from the genus Bacteriovorax of which the complete genome has been sequenced and reported.

To date, variations in the 16S rRNA sequences have yielded approximately eight Bacteriovorax clusters or OTUs. The previously sequenced Bacteriovorax marinus $\mathrm{SJ}^{\mathrm{T}}$ is one of the representatives that belong to phylogenetic Cluster III. This classification scheme has enabled for the first time the detection of specific Bacteriovorax strains in environmental/ecological studies. The validity of using the 16S rRNA gene was tested by comparison with the $r p o B$ gene [10]. The results of recent studies monitoring the activities and distribution of specific phylogenetic 
clusters have yielded new discoveries on the distribution, predation patterns, prey preferences, and ecology of this bacterial predator [14-16].

Here we present a description of the draft genomes of Bacteriovorax isolates of four phylogenetic clusters isolated from estuarine systems, together with the description of the genomic sequencing and annotation.

\section{Organism information}

A 16S rRNA phylogenetic tree was constructed showing the phylogenetic neighborhood of the four newly sequenced Bacteriovorax strains within the family of Bdellovibrionaceae (Figure 1). As expected, Bacteriovorax sp. strain BSW11_IV was grouped together with cluster IV, strain SEQ25 _V with cluster V, Strain DB6_IX with Cluster IX and lastly strain BAL6_X with cluster X.

General features of Bacteriovorax spp. are summarized in Table 1. Individual features of Bacteriovorax isolates have not been sufficiently explored and are largely unknown. Micrographs generated by both transmission electron microscopy and scanning microscopy (Figure 2) suggest that Bacteriovorax spp. employ similar predation

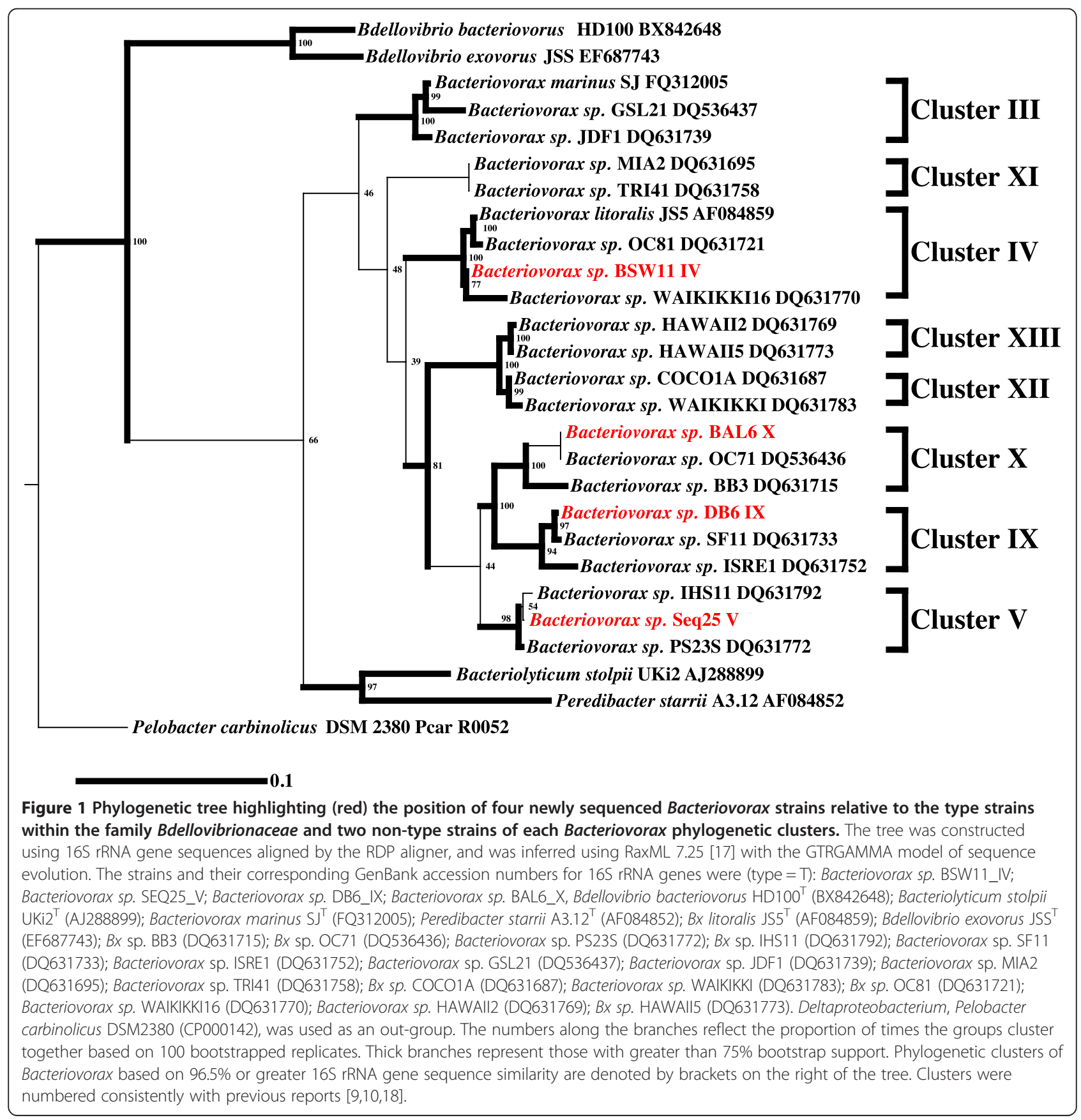


Table 1 Classification and general features of Bacteriovorax strains according to the MIGS recommendations [19]

\begin{tabular}{|c|c|c|c|c|}
\hline \multirow[t]{2}{*}{ MIGS ID } & \multirow{2}{*}{$\begin{array}{l}\text { Property } \\
\text { Current classification }\end{array}$} & \multicolumn{2}{|l|}{ Term } & \multirow{2}{*}{$\begin{array}{l}\text { Evidence code } \\
\text { TAS [20] }\end{array}$} \\
\hline & & Domain & Bacteria & \\
\hline & & Phylum & Proteobacteria & TAS [21] \\
\hline & & Class & Deltaproteobacteria & $\operatorname{TAS}[22,23]$ \\
\hline & & Order & Bdellovibrionales & TAS [24] \\
\hline & & Family & Bacteriovoracaceae & TAS [25] \\
\hline & & Genus & Bacteriovorax & TAS [3] \\
\hline & & Species & Cluster IV, Cluster V, Cluster IX, Cluster X & TAS [18] \\
\hline & & Strains: & BSW11_IV, SEQ25_V, DB6_IX, BAL6_X & IDA \\
\hline & Gram stain & \multicolumn{2}{|l|}{ Negative } & TAS [26] \\
\hline & Cell shape & \multicolumn{2}{|c|}{ comma-shaped, 0.35-1.2 $\mu \mathrm{m}$} & TAS [26] \\
\hline & Motility & \multicolumn{2}{|c|}{ motile (one single, polar, sheathed flagellum) } & TAS [26] \\
\hline & Sporulation & \multicolumn{2}{|c|}{ Non-sporulating } & NAS \\
\hline & Temperature range & \multicolumn{2}{|l|}{$10-35^{\circ} \mathrm{C}$} & TAS [13] \\
\hline & Optimum temperature & \multicolumn{2}{|l|}{$15-30^{\circ} \mathrm{C}$} & TAS [3] \\
\hline & Carbon source & \multicolumn{2}{|c|}{ Peptides, proteins } & TAS [13] \\
\hline & Energy source & \multicolumn{2}{|c|}{ Chemo-organotroph } & TAS [13] \\
\hline & Terminal electron receptor & \multicolumn{2}{|c|}{ Unknown } & IDA \\
\hline MIGS-6 & Habitat & \multicolumn{2}{|c|}{ marine, estuarine } & TAS [18] \\
\hline MIGS-6.3 & Salinity & \multicolumn{2}{|l|}{$>0.5 \%$} & TAS [3] \\
\hline MIGS-22 & Oxygen & \multicolumn{2}{|l|}{ Aerobic } & NAS \\
\hline MIGS-15 & Biotic relationship & \multicolumn{2}{|c|}{ free living/ parasitic } & TAS [3] \\
\hline MIGS-14 & Pathogenicity & \multicolumn{2}{|c|}{ Not reported } & TAS [3] \\
\hline \multirow[t]{3}{*}{ MIGS-4 } & Geographic location & \multicolumn{2}{|c|}{ Breton Sound, LA (BSW11_IV); } & IDA \\
\hline & & \multicolumn{3}{|c|}{ Barataria Bay, LA (SEQ25_V); } \\
\hline & & \multicolumn{3}{|c|}{ Apalachicola Bay, FL (DB6_IX, BAL6_X) } \\
\hline \multirow[t]{3}{*}{ MIGS-5 } & Sample collection time & \multicolumn{2}{|c|}{ April, 2011 (BSW11_IV); } & IDA \\
\hline & & \multicolumn{2}{|c|}{ June, 2011 (SEQ25_V); } & \\
\hline & & \multicolumn{2}{|c|}{ October, 2010 (DB6_IX, , BAL6_X) } & \\
\hline \multirow[t]{3}{*}{ MIGS-4.1 MIGS-4.2 } & Latitude - Longitude & \multicolumn{2}{|c|}{29.63 -89.66 (BSW11_IV); } & IDA, TAS [14] \\
\hline & & \multicolumn{2}{|c|}{29.38 -89.98 (SEQ25_V); } & \\
\hline & & $29.67-85$ & IX, BAL6_X) & \\
\hline MIGS-4.3 & Depth & not repo & N11_IV, SEQ25_V); & NAS,TAS [14] \\
\hline & & $1.74 \mathrm{~m}($ & BAL6_X) & \\
\hline MIGS-4.4 & Altitude & not repo & & IDA \\
\hline
\end{tabular}

${ }^{a}$ Evidence codes - IDA: Inferred from Direct Assay; TAS: Traceable Author Statement (i.e., a direct report exists in the literature); NAS: Non-traceable Author Statement (i.e., not directly observed for the living, isolated sample, but based on a generally accepted property for the species, or anecdotal evidence). These evidence codes are from the Gene Ontology project [27].

strategies as other BALO members to attack and reside in the periplasic space of its prey.

\section{Genome sequencing information Genome project history}

The four genomes were selected for sequencing on the basis of their phylogenetic position and isolation source. Low salt Bacteriovorax sp. BSW11_IV was isolated from Breton Sound, Louisiana (salinity 0.6 ppt; Temperature $26.4^{\circ} \mathrm{C}$ ) and SEQ25_V was obtained from water samples of Barataria Bay, Louisiana (salinity 5.2 ppt; Temperature $19.2^{\circ} \mathrm{C}$ ). High salt DB6_IX (Salinity $32.4 \mathrm{ppt}$; Temperature $24.1^{\circ} \mathrm{C}$ ) and BAL6_ X (Salinity 30.9 ppt; Temperature $25.2^{\circ} \mathrm{C}$ ) were obtained from Apalachicola Bay, Florida. The genome sequences were deposited in GenBank. Sequencing and annotation were performed at the J. Craig Venter Institute. Table 2 presents the project information and its association with MIGS version 2.0 compliance [19]. 

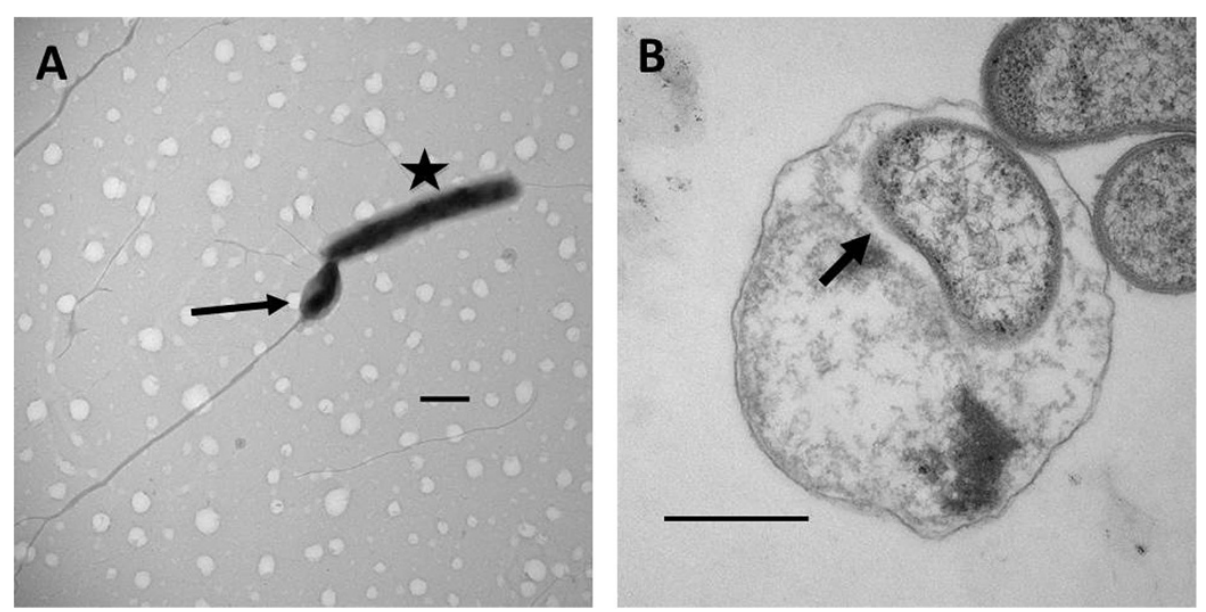

Figure 2 Electron micrographs showing (A) Bx sp. DB6_IX (arrow) attached to the polar end of the prey cell V. vulnificus (Star); (B) thin sections of bdelloplast, the post-BALO infection structure with the predator (arrow) residing inside the prey cell. Scale Bar represents $500 \mathrm{~nm}$.

\section{Growth conditions and DNA isolation}

Bacteriovorax cultures were grown separately in 70\% artificial sea water (ASW) (Instant Ocean, Aquarium Systems, Inc., Mentor, Ohio) (pH 8, salinity 22 ppt.) amended with prey, Vibrio. vulnificus CMCP6 (for Bx $s p$. BSW11_IV and SEQ25_V), or V. parahaemolyticus RIMD 2210633 (for Bacteriovorax sp. DB6_IX and BAL6_X). The genomes of both prey bacteria have been sequenced previously $[28,29]$. When cultures became clear (2-3 days after inoculation of the prey), which indicated the majority of the prey cells were lysed by the predators, $300 \mathrm{ml}$ suspensions were filtered consecutively through 0.45 and $0.22 \mu \mathrm{m}$ sterile syringe filters (Corning, NY, USA) to remove any remaining prey. Filtrates containing high concentrations of Bacteriovorax cells (ca. $4 \times 10^{8} \mathrm{PFU} \mathrm{ml}^{-1}$ ) were centrifuged at $27,485 \times \mathrm{g}$ for $20 \mathrm{~min}$ at $4^{\circ} \mathrm{C}$. The pellets were then re-suspended in $1 \mathrm{ml}$ of ASW respectively. To test that the concentrated Bacteriovorax suspensions were free of prey cell contamination, aliquots of $0.1 \mathrm{ml}$ of the filtrate were spread-plated onto LB agar and incubated at $37^{\circ} \mathrm{C}$ for two days.

Subsequently, total DNA from the cell pellets were extracted using the QIAGEN Kit (QIAamp DNA Mini Kit), according to the manufacturer's protocol. The concentration and purity of DNA was measured by a NanoDrop Spectrophotometer (ND 1000, Thermo Fisher Scientific, DE). To reconfirm the phylotype of the isolations, the DNA was PCR amplified using Bacteriovorax specific primers, Bac-676 F (5'-ATT TCG CAT GTA GGG GTA-3') and Bac-1442R (5'-GCC ACG GCT TCA GGT AAG-3') [30] by puReTaq Ready-To-Go PCR Beads (GE Healthcare Bio-Sciences). PCR products were purified

Table 2 Genome sequencing project information

\begin{tabular}{|c|c|c|c|c|c|}
\hline MIGS ID & Property & BSW11_IV & SEQ25_V & DB6_IX & BAL6_X \\
\hline MIGS-31 & Finishing quality & $\begin{array}{l}\text { improved-high-quality } \\
\text { draft }\end{array}$ & $\begin{array}{l}\text { improved-high-quality } \\
\text { draft }\end{array}$ & $\begin{array}{l}\text { improved-high-quality } \\
\text { draft }\end{array}$ & $\begin{array}{l}\text { improved-high-quality } \\
\text { draft }\end{array}$ \\
\hline MIGS-28 & Libraries used & $\begin{array}{l}3 \mathrm{~KB} 454 \mathrm{PE}, 327 \mathrm{bp} \text { avg. } \\
\text { insert Illumina fragment }\end{array}$ & $\begin{array}{l}3 \mathrm{~KB} 454 \mathrm{PE}, 335 \mathrm{bp} \text { avg. } \\
\text { insert Illumina fragment }\end{array}$ & $\begin{array}{l}3 \mathrm{~KB} 454 \mathrm{PE}, 346 \text { bp avg. } \\
\text { insert Illumina fragment }\end{array}$ & $\begin{array}{l}3 \mathrm{~KB} 454 \mathrm{PE}, 316 \mathrm{bp} \text { avg. } \\
\text { insert Illumina fragment }\end{array}$ \\
\hline IGS-29 & Sequencing platforms & $\begin{array}{l}\text { Illumina GAll, } 454 \text { GS FLX } \\
\text { Titanium }\end{array}$ & $\begin{array}{l}\text { Illumina GAll, } 454 \text { GS FLX } \\
\text { Titanium }\end{array}$ & $\begin{array}{l}\text { Illumina GAll, } 454 \text { GS FLX } \\
\text { Titanium }\end{array}$ & $\begin{array}{l}\text { Illumina GAll, } 454 \text { GS FLX } \\
\text { Titanium }\end{array}$ \\
\hline MIGS-31.2 & Fold coverage & $700 \times$ hybrid coverage & $85 \times$ hybrid coverage & $583 \times$ hybrid coverage & $81 \times$ hybrid coverage \\
\hline MIGS-30 & Assemblers & Newbler 2.6 & CLC 5.0 & CA 7.0 & CA 7.0 \\
\hline \multirow[t]{5}{*}{ MIGS-32 } & Gene calling method & Glimmer 3.02 & Glimmer 3.02 & Glimmer 3.02 & Glimmer 3.02 \\
\hline & Genome Database release & August 16, 2013 & August 16, 2013 & August 16, 2013 & August 5, 2013 \\
\hline & Genbank ID & PRJNA210325 & PRJNA210326 & PRJNA210327 & PRJNA210328 \\
\hline & Genbank Date of Release & August 16, 2013 & August 16, 2013 & August 16, 2013 & August 5, 2013 \\
\hline & GOLD ID & Gi0051698 & Gi19265 & Gi0051699 & G0i005170 \\
\hline MIGS-13 & Project relevance & Environment & Environment & Environment & Environment \\
\hline
\end{tabular}


Table 3 Summary of genomes

\begin{tabular}{llll}
\hline Label & Size $(\mathbf{M b})$ & Topology & INSDC identifier \\
\hline BSW11_IV & 3.65 & Circular & PRJNA210325 \\
SEQ25_V & 3.45 & Circular & PRJNA210326 \\
DB6_IX & 2.97 & Circular & PRJNA210327 \\
BAL6_X & 3.23 & Circular & PRJNA210328 \\
\hline
\end{tabular}

with the QIAquick PCR-Purification Kit (QIAGEN) and sequenced with Bac-676 F primer at the DNA Sequencing Laboratory at Florida State University. 16S DNA sequences were analyzed with the Basic Local Alignment Search Tool (BLAST) server from the National Center of Biotechnology Information [31].

\section{Genome sequencing and assembly}

Genome sequencing of the four Bacteriovorax isolates was conducted at the J. Craig Venter Institute employing a combination of Illumina and 454 sequencing platforms. The 454 data consisted of a half plate of 454 FLX per genome from $3 \mathrm{~KB}$ mate paired libraries. The Illumina data consisted of one-quarter lane of $2 \times 100 \mathrm{bp}$ Illumina HiSeq data per genome. On average, 300,000 454 reads (average length trimmed $300 \mathrm{bp}$ ) and 10 million Illumina sequences (average length trimmed $100 \mathrm{bp}$ ) were generated per genome. To incorporate a hybrid assembly using both 454 and Illumina sequence libraries, one million reads were randomly sampled (with their mates) from the Illumina library using Celera [32], which was sufficient to provide high coverage in the initial assemblies.

\section{Genome annotation}

Genes were identified using GLIMMER3 [33] as part of the JCVI prokaryotic annotation pipeline followed by manual curation using the Manatee annotation-editing platform. The JCVI automated pipeline incorporates HMM3 [34] searches against Pfam [35] and TIGRFAMs [36] and BLASTP against UniProt [37], JCVI's database of experimentally characterized proteins CharProt DB [38], and PIR [39].

\section{Genome properties}

The Bacteriovorax sp. BSW11_ IV draft genome contains 3,650,096 bp with a GC content of $37 \%$. The hybrid assembly was scanned for contamination using BlastP and the appropriate contigs were filtered out. The final assembly comprised of 3 scafolds, 30 RNAs and 3457 CDS. For the CDSs, 2591 (75\%) proteins had a BLASTP hit with an e-value of 1e-9 or better to Bacteriovorax marinus SJ, and an additional 151 (4\%) CDSs had a hit within the genus Bdellovibrio.

The Bacteriovorax sp. SEQ25_V draft genome contains $3,450,786$ bp with a GC content of $37 \%$. The sequences were assembled into 29 contigs comprised of 35 RNAs and 3,292 CDSs. Among the CDSs, 2,456 (75\%) of proteins had a BLASTP hit with an e-value of 1e- 9 or better to Bacteriovorax marinus SJ, and an additional 131 (4\%) CDSs had a hit within the genus Bdellovibrio.

The Bacteriovorax sp. DB6_IX draft genome contains $2,969,235$ bp with a GC content of $38 \%$. Sequences were assembled into 10 scaffolds with 30 RNAs and 3192 CDSs. Among theCDSs 2,253 (71\%) proteins had a BLASTP hit with an e-value of $1 \mathrm{e}-9$ or better to $B x$ marinus SJ, and an additional 97 (3\%) CDSs had a hit within the genus Bdellovibrio.

The Bacteriovorax sp. BAL6_ X draft genome contains $3,233,679$ bp with a GC content of $36 \%$. The reads were assembled into 9 contigs with 37 RNAs and 3,065 CDSs. Among the CDSs, 2,298 (72\%) proteins had a BLASTP hit with an e-value of 1e- 9 or better to Bacteriovorax marinus SJ, and an additional 92 (3\%) CDSs had a hit within the genus Bdellovibrio.

It is noteworthy to point out that three phage tail fiber proteins were identified within the $B x$ sp. BSW11_IV genome but were absent from all the other BALO genome including the completed Bacteriovorax marinus SJ and Bdellovibrio bacteriovorus HD100 genomes. A staphylococcal phi-Mu50B-like prophage element was present in both SJ and HD 100 genomes but was not found in the genomes of the four newly sequenced Bacteriovorax isolates. The properties and the statistics of the genome are summarized in Tables 3, 4 and 5 and (Additional file 1: Table S1).

Table 4 Nucleotide content and gene count levels of the genome

\begin{tabular}{|c|c|c|c|c|c|c|c|c|}
\hline & \multicolumn{2}{|l|}{ BSW11_IV } & \multicolumn{2}{|l|}{ SEQ25_V } & \multicolumn{2}{|l|}{ DB6_IX } & \multicolumn{2}{|l|}{ BAL6_X } \\
\hline & Value & $\%$ of total ${ }^{a}$ & Value & $\%$ of total ${ }^{a}$ & Value & $\%$ of total ${ }^{\mathrm{a}}$ & Value & $\%$ of total ${ }^{a}$ \\
\hline$\overline{\text { Genome size (bp) }}$ & $3,650,096$ & $100.00 \%$ & $3,450,786$ & $100.00 \%$ & $2,969,235$ & $100.00 \%$ & $3,233,679$ & $100.00 \%$ \\
\hline$G+C$ content $(b p)$ & $1,347,908$ & $36.93 \%$ & $1,243,844$ & $36.05 \%$ & $1,117,420$ & $37.63 \%$ & $1,179,198$ & $36.47 \%$ \\
\hline Total genes & 3,487 & $100.00 \%$ & 3,327 & $100.00 \%$ & 3,222 & $100.00 \%$ & 3,102 & $100.00 \%$ \\
\hline RNA genes & 30 & $0.86 \%$ & 35 & $1.05 \%$ & 30 & $0.93 \%$ & 37 & $1.19 \%$ \\
\hline Protein-coding genes & 3,457 & $99.14 \%$ & 3,292 & $98.95 \%$ & 3,192 & $99.07 \%$ & 3,065 & $98.81 \%$ \\
\hline Proteins assigned to COGs & 2,144 & $62.02 \%$ & 2,045 & $62.12 \%$ & 1,911 & $59.87 \%$ & 1,815 & $59.22 \%$ \\
\hline Proteins with transmembrane helices & 708 & $20.48 \%$ & 650 & $19.74 \%$ & 578 & $18.11 \%$ & 661 & $21.57 \%$ \\
\hline
\end{tabular}

a) The total is based on either the size of the genome in base pairs or the total number of protein coding genes in the annotated genome. 
Table $\mathbf{5}$ Number of genes associated with the $\mathbf{2 5}$ general COG functional categories

\begin{tabular}{|c|c|c|c|c|c|c|c|c|c|}
\hline \multirow{2}{*}{ Code } & \multicolumn{2}{|c|}{ BSW11_IV } & \multicolumn{2}{|c|}{ SEQ25_V } & \multicolumn{2}{|c|}{ DB6_IX } & \multicolumn{2}{|c|}{ BAL6_X } & \multirow[b]{2}{*}{ Description } \\
\hline & Value & $\%$ of total ${ }^{\mathrm{a}}$ & Value & $\%$ of total & Value & $\%$ of total & Value & $\%$ of total & \\
\hline J & 166 & 4.80 & 167 & 5.07 & 137 & 4.29 & 163 & 5.31 & Translation \\
\hline A & 0 & 0.00 & 0 & 0.00 & 0 & 0.00 & 0 & 0.00 & RNA processing and modification \\
\hline K & 126 & 3.64 & 121 & 3.67 & 109 & 3.41 & 108 & 3.52 & Transcription \\
\hline L & 115 & 3.32 & 103 & 3.12 & 100 & 3.13 & 112 & 3.65 & Replication and repair \\
\hline B & 1 & 0.03 & 1 & 0.03 & 2 & 0.06 & 1 & 0.03 & Chromatin structure and dynamics \\
\hline D & 24 & 0.69 & 27 & 0.82 & 23 & 0.72 & 29 & 0.94 & Cell cycle control and mitosis \\
\hline Y & 0 & 0.00 & 0 & 0.00 & 0 & 0.00 & 0 & 0.00 & Nuclear structure \\
\hline V & 45 & 1.3 & 34 & 1.03 & 31 & 0.97 & 40 & 1.30 & Defense mechanisms \\
\hline $\mathrm{T}$ & 229 & 6.62 & 205 & 6.22 & 219 & 6.86 & 126 & 4.11 & Signal transduction mechanisms \\
\hline M & 155 & 4.48 & 161 & 4.89 & 129 & 4.04 & 140 & 4.56 & Cell wall/membrane/biogenesis \\
\hline N & 95 & 2.74 & 82 & 2.49 & 68 & 2.13 & 71 & 2.31 & Cell motility \\
\hline Z & 2 & 0.06 & 3 & 0.09 & 2 & 0.06 & 3 & 0.10 & Cytoskeleton \\
\hline W & 21 & 0.61 & 22 & 0.67 & 16 & 0.50 & 19 & 0.62 & Extracellular structures \\
\hline$U$ & 43 & 1.42 & 43 & 1.31 & 38 & 1.19 & 44 & 1.43 & Intracellular trafficking and secretion \\
\hline $\mathrm{O}$ & 125 & 3.61 & 118 & 3.58 & 97 & 3.03 & 118 & 3.84 & $\begin{array}{l}\text { Posttranslational modification, } \\
\text { protein turnover, chaperones }\end{array}$ \\
\hline C & 117 & 3.38 & 123 & 3.73 & 106 & 3.32 & 112 & 3.65 & Energy production and conversion \\
\hline G & 72 & 2.08 & 80 & 2.43 & 67 & 2.09 & 53 & 1.72 & Carbohydrate transport and metabolism \\
\hline E & 192 & 5.55 & 166 & 5.04 & 166 & 5.20 & 138 & 4.50 & Amino Acid transport and metabolism \\
\hline $\mathrm{F}$ & 53 & $1.53 \mathrm{~s}$ & 51 & 1.54 & 65 & 2.03 & 49 & 1.59 & Nucleotide transport and metabolism \\
\hline $\mathrm{H}$ & 76 & 2.19 & 83 & 2.52 & 72 & 2.25 & 73 & 2.38 & Coenzyme transport and metabolism \\
\hline I & 108 & 3.12 & 91 & 2.76 & 104 & 3.25 & 96 & 3.13 & Lipid transport and metabolism \\
\hline$P$ & 90 & 2.60 & 84 & 2.55 & 88 & 2.75 & 87 & 2.83 & Inorganic ion transport and metabolism \\
\hline Q & 54 & 1.56 & 60 & 1.82 & 69 & 2.16 & 48 & 1.56 & $\begin{array}{l}\text { Secondary metabolites biosynthesis, } \\
\text { transport and catabolism }\end{array}$ \\
\hline $\mathrm{R}$ & 308 & 8.90 & 296 & 8.99 & 274 & 8.58 & 262 & 8.54 & General Functional Prediction only \\
\hline S & 156 & 4.51 & 150 & 4.55 & 124 & 3.88 & 142 & 4.63 & Function Unknown \\
\hline- & 1372 & 39.68 & 1293 & 39.27 & 1355 & 42.44 & 1244 & 40.58 & Not in COG \\
\hline
\end{tabular}

${ }^{a}$ The total is based on the total number of protein coding genes in the annotated genome.

\section{Insights from the genome sequences}

\section{Genome Comparisons between BALO Members}

Crossman et al., [40] reported that the genomic sequences of Bacteriovorax marinus SJ were unique with about one third of predicted genes over $500 \mathrm{bp}$ in length having no significant hit in the databases. No genomic synteny was found between SJ and its closest whole genome sequenced relative at that time, Bdellovibrio bacteriovorus HD100.

We found that even within the genus Bacteriovorax, the genomic sequences were highly divergent with an average identity of $70 \%$. A Venn diagram summarizing the comparison of the four Bacteriovorax isolates is presented in Figure 3. As shown in the diagram, a core of 1,513 proteins is shared by all four Bacteriovorax genomes and each encodes many proteins without orthologs in the other three (Figure 3A). When compared to the freshwater/ terrestrial Bdellovibrio bacteriovorus HD 100, only a total of 843 genes were shared between all BALO members (Figure 3B). The calculated ANI [41] for BALO members (Additional file 2: Table S2) is below 75\%, which is the threshold for the scores to be reliable. The AAI among the five Bacteriovorax genomes ranged between $50 \%$ to $60 \%$ (Additional file 3: Table S3), also significantly lower than the typical values found for species within a genus (73\%-99.5\%) [42,43]. Currently, several proposals to clarify and revise the systematics of BALOs are under consideration.

\section{Comparisons of BALOs and non-predatory bacteria}

Phylogenetically, most genera of BALOs (including Bacteriovorax) are classified as Deltaproteobacteria. Members of this class are found in diverse environments with various lifestyles such as Myxococcus xanthus which is 

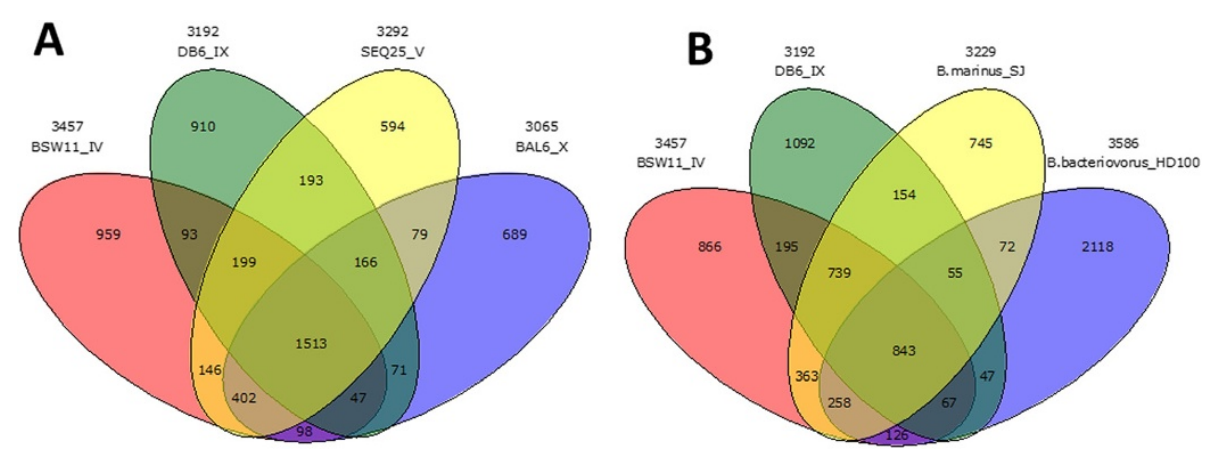

Figure 3 Venn diagram of shared and unique genes in (A) the four newly sequenced Bacteriovorax isolates, (B) three Bacteriovorax strains and Bdellovibrio bacteriovorus HD100. Orthology was assumed using the best reciprocal BLASTP matches (cutoff $P$ value $=10-9$ ).

characterized by its gliding motility and wolf pack predatory strategy to prey on other bacteria [44], Pelobacter carbinolicus which grows by using iron and sulfur as electron acceptors [45], and the focus of this study, the obligate predators Bacteriovorax spp. which replicate within the periplasmic space of prey bacteria. Although their ecological features are distinct, the genomes of Deltaproteobacteria were found to exhibit some common characteristics. For example, most Deltaproteobacteria, including the Bdellovibrio bacteriovorus HD 100, typically possess two giant S1 ribosomal protein genes and high numbers of TonB receptors and ferric siderophore receptors which facilitate metal uptake and removal [46]. In contrast, only one giant S1 protein was found in the Bacteriovorax marinus SJ genome [40], and our study confirmed that this is the case for the other four Bacteriovorax genomes. Bacteriovorax genomes also encodes multiple TonB receptor proteins (6-11 copies) and ferric siderophore receptors (2-4 copies) that they may use for predation.

Using a reciprocal best match analysis with e-value cutoff of 10-9, 843 core genes were found to contain orthologs in all six BALO genomes including previously sequenced SJ and HD 100 genomes (see center of Figure 3B). Fifty nine of these genes (Additional file 4: Table S4) have no homologs with an E-value of 10-9 or lower to proteins from any non-predatory bacterium in the NCBI "nr" database. These genes, including periplasmic proteins, a radical activating enzyme and an outer membrane channel protein, may represent a core set of unique genes involved in the predatory process and prey interactions such as locating the prey, degradation and consumption of prey cellular content, formation of bdelloplast, synchronous nonbinary septation or release of progeny from the ghost cell.

\section{Conclusion}

The genomes of four Bacteriovorax phylogenetic clusters isolated from the environment were sequenced. The genome sizes of the four strains were comparable with
Bacteriovorax SJ but were slightly smaller than the two freshwater BALOs, Bdellovibrio bacteriovorus Tiberius and B. bacteriovorus HD100. Fifty-nine genes were identified that are conserved among BALOs, but not present in other organisms, that may be responsible for their predatory life style. The unique genomic features of Bacteriovorax that are essential for their ecological function were also reported.

\section{Additional files}

\begin{abstract}
Additional file 1: Table S1. Associated MIGS record.
Additional file 2: Table S2. Comparison of the average nucleotide identity (ANI) for the BALO genomes. ANI was calculated using ANI.pl script (https://github.com/chjp/ANI/blob/master/ANI.pl). All values are in percentages.

Additional file 3: Table S3. Percentage of average amino acid identity (AAI) between BALO genomes. AAI calculation of all two-way BLAST conserved genes was computed using AAl.rb script (http://enveomics.blogspot.com/2013/10/aairb.html).

Additional file 4: Table S4. Annotation of genes that are present in all BALO members but have no homologs from any non-predatory bacterium in NCBI's " $n r^{\prime \prime}$ database (E-value $<10^{-9}$ ). Genes are listed by the protein number in BALO genomes.
\end{abstract}

\section{Abbreviations}

BALOs: Bdellovibrio and Like Organisms; ANI: Average nucleotide identity; AAl: Average amino acid identity.

\section{Competing interests}

The authors declare that they have no competing interests.

\section{Authors' contributions}

$J H B$ and HNW initiated and supervised the study. HC draft the manuscript, conducted wetlab work and performed electron microscopy. HC, LMB, DSL, TLD and NG annotated the genome. HC, PM, LMB and JHB worked on genome sequencing and assembly. HC, NL, JHB, PM and HNW discussed, analyzed the data and revised the manuscript. All authors read and approved the final manuscript.

\section{Acknowledgements}

This work was financially supported by grants from the National Science Foundation HBCU-RISE (\#0531523) and DDIG (DEB-1110620). We thank the assistance of Drs Jill W Verlander and Sharon W Matthews at the University of Florida, College of Medicine Electron Microscopy Facility; Megan Lamb at Apalachicola Bay, National Estuarine Research Reserve for research vessel operation and Dr. Aixin Hou at the Louisiana State University for assisting in 
sample collection and providing laboratory space for initial processing of samples.

\section{Author details}

${ }^{1}$ Florida A\&M University, Tallahassee, USA. ${ }^{2}$ National High Magnetic Field Laboratory, Florida State University, Tallahassee, FL 32310-4005, USA. ${ }^{3}$ J Craig Venter Institute, Rockville, MD 20850, USA. ${ }^{4}$ J Craig Venter Institute, La Jolla, CA 92037, USA.

\section{Received: 16 June 2014 Accepted: 1 December 2014}

\section{Published: 24 March 2015}

\section{References}

1. Rendulic S, Jagtap P, Rosinus A, Eppinger M, Baar C, Lanz C. A predator unmasked: life cycle of Bdellovibrio bacteriovorus from a genomic perspective. Science. 2004;303:689-92.

2. Hobley L, Lerner TR, Williams LE, Lambert C, Till R, Milner DS, et al. Genome analysis of a simultaneously predatory and prey-independent, novel Bdellovibrio bacteriovorus from the River Tiber, supports in silico predictions of both ancient and recent lateral gene transfer from diverse bacteria. BMC Genomics. 2012;13:670.

3. Baer ML, Ravel J, Pineiro SA, Guether-Borg D, Williams HN. Reclassification of salt-water Bdellovibrio sp. as Bacteriovorax marinus sp. nov. and Bacteriovorax litoralis sp. nov. Int J Syst Evol Microbiol. 2004;54:1011-6.

4. Chen $\mathrm{H}$, Williams HN. Sharing of prey: coinfection of a bacterium by a virus and a prokaryotic predator. MBio 2012;3(2):e00051-12.

5. Atterbury RJ, Hobley L, Till R, Lambert C, Capeness MJ, Lerner TR, et al. Effects of orally administered Bdellovibrio bacteriovorus on the well-being and Salmonella colonization of young chicks. Appl Environ Microbiol. 2011;77:5794-803.

6. Dashiff A, Junka R, Libera M, Kadouri D. Predation of human pathogens by the predatory bacteria Micavibrio aeruginosavorus and Bdellovibrio bacteriovorus. J Appl Microbiol. 2011;110:431-44.

7. Cao H, Hou S, He S, Lu L, Yang X. Identification of a Bacteriovorax sp. isolate as a potential biocontrol bacterium against snakehead fish-pathogenic Aeromonas veronii. J Fish Dis. 2013;37(3):283-289.

8. Baer ML, Ravel J, Chun J, Hill RT, Williams HN. A proposal for the reclassification of Bdellovibrio stolpii and Bdellovibrio starrii into a new genus, Bacteriovorax gen. nov. as Bacteriovorax stolpii comb. nov. and Bacteriovorax starrii comb. nov., respectively. Int J Syst Evol Microbiol. 2000;50 Pt 1:219-24.

9. Davidov $Y$, Jurkevitch E. Diversity and evolution of Bdellovibrio-and-like organisms (BALOs), reclassification of Bacteriovorax starrii as Peredibacter starrii gen. nov., comb. nov., and description of the Bacteriovorax-Peredibacter clade as Bacteriovoracaceae fam. nov. Int J Syst Evol Microbiol. 2004;54:1439-52.

10. Pineiro SA, Williams HN, Stine OC. Phylogenetic relationships amongst the saltwater members of the genus Bacteriovorax using rpoB sequences and reclassification of Bacteriovorax stolpii as Bacteriolyticum stolpii gen. nov., comb. nov. Int J Syst Evol Microbiol. 2008;58:1203-9.

11. Schoeffield AJ, Williams HN. Efficiencies of Recovery of Bdellovibrios from Brackish- Water Environments by Using Various Bacterial Species as Prey. Appl Environ Microbiol. 1990;56:230-6.

12. Williams HN. Cultural, immunologic and ecologic studies of marine bdellovibrios isolated from the Atlantic Ocean and the Chesapeake Bay. Baltimore, MD, USA: University of Maryland; 1979.

13. Marbach A, Varon M, Shilo M. Properties of marine bdellovibrios. Microb Ecol. 1976;2:284-95.

14. Chen H, Young S, Berhane T-K, Williams HN. Predatory Bacteriovorax Communities Ordered by Various Prey Species. PLoS ONE. 2012;7:e34174

15. Chauhan A, Cherrier J, Williams HN. Impact of sideways and bottom-up control factors on bacterial community succession over a tidal cycle. Proc Natl Acad Sci U S A. 2009;106:4301-6.

16. Chen $H$, Athar R, Zheng G, Williams HN. Prey bacteria shape the community structure of their predators. ISME J. 2011;5:1314-22

17. Stamatakis A, Hoover P, Rougemont J. A rapid bootstrap algorithm for the RAxML web servers. Syst Biol. 2008;57:758-71.

18. Pineiro S, Stine O, Chauhan A, Steyert S, Smith R, Williams H. Global survey of diversity among environmental saltwater Bacteriovoracaceae. Environ Microbiol. 2007:9:2441-50.

19. Field D, Garrity G, Gray T, Morrison N, Selengut J, Sterk P, et al. The minimum information about a genome sequence (MIGS) specification. Nat Biotechnol. 2008;26:541-7.
20. Woese CR, Kandler O, Wheelis ML. Towards a natural system of organisms: proposal for the domains Archaea, Bacteria, and Eucarya. Proc Natl Acad Sci U S A. 1990;87:4576-9.

21. Garrity GM, Holt JG. The Road Map to the Manual. In: Garrity GM, Boone DR, Castenholz RW, editors. Bergey's Manual of Systematic Bacteriology, vol. 1. 2nd ed. New York: Springer; 2001. p. 119-69.

22. Validation List No. 107: List of new names and new combinations previously effectively, but not validly, published. Int J Syst Evol Microbiol. 2006;56:1-6.

23. Kuever J, Rainey FA, Widdel F. Class VI. Deltaproteobacteria class nov. In: Brenner DJ, Krieg NR, Staley JT, Garrity GM, editors. Bergey's Manual of Systematic Bacteriology. Volume 2, part C. 2nd ed. New York: Springer; 2005.

24. Garrity GM, Bell JA, Lilburn T. Order VII. Bdellovibrionales ord. nov. In: Brenner DJ, Krieg NR, Staley JT, Garrity GM, editors. Bergey's Manual of Systematic Bacteriology. Volume 2, Part C. 2nd ed. New York: Springer; 2005. p. 1040.

25. Garrity GM, Bell JA, Lilburn T. Family I. Bdellovibrionaceae fam. nov. In: Brenner DJ, Krieg NR, Staley JT, Garrity GM, editors. Bergey's Manual of Systematic Bacteriology. Volume 2, Part C. 2nd ed. New York: Springer; 2005. p. 1040-1.

26. Williams H, Baer M, Tudor J. Bdellovibrio Stolp and Starr 1963, 243 AL. In: Bergey's Manual ${ }^{\circledR}$ of Systematic Bacteriology. 2005. p. 1041-53.

27. Ashburner M, Ball CA, Blake JA, Botstein D, Butler H, Cherry JM, et al. Gene ontology: tool for the unification of biology. The Gene Ontology Consortium. Nat Genet. 2000;25:25-9.

28. Makino K, Oshima K, Kurokawa K, Yokoyama K, Uda T, Tagomori K, et al. Genome sequence of Vibrio parahaemolyticus: a pathogenic mechanism distinct from that of $V$. cholerae. Lancet. 2003;361:743-9.

29. Kim YR, Lee SE, Kim CM, Kim SY, Shin EK, Shin DH, et al. Characterization and pathogenic significance of Vibrio vulnificus antigens preferentially expressed in septicemic patients. Infect Immun. 2003;71:5461.

30. Davidov Y, Friedjung A, Jurkevitch E. Structure analysis of a soil community of predatory bacteria using culture-dependent and culture-independent methods reveals a hitherto undetected diversity of Bdellovibrio-and-like organisms. Environ Microbiol. 2006:8:1667-73.

31. Altschul SF, Gish W, Miller W, Myers EW, Lipman DJ. Basic local alignment search tool. J Mol Biol 1990;215(3):403-410.

32. Miller JR, Delcher AL, Koren S, Venter E, Walenz BP, Brownley A, et al. Aggressive assembly of pyrosequencing reads with mates. Bioinformatics. 2008;24:2818-24.

33. Delcher AL, Harmon D, Kasif S, White O, Salzberg SL. Improved microbial gene identification with GLIMMER. Nucleic Acids Res. 1999;27:4636-41.

34. Eddy SR. Accelerated profile HMM searches. PLoS Comput Biol. 2011;7:e1002195.

35. Finn RD, Clements J, Eddy SR. HMMER web server: interactive sequence similarity searching. Nucleic Acids Res. 2011;39:W29-37.

36. Haft DH, Selengut JD, Richter RA, Harkins D, Basu MK, Beck E. TIGRFAMs and genome properties in 2013. Nucleic Acids Res. 2013;41:D387-95.

37. Magrane M. UniProt Knowledgebase: a hub of integrated protein data. Database: J Biol Dat Curation. 2011;2011.

38. Madupu R, Richter A, Dodson RJ, Brinkac L, Harkins D, Durkin S, et al. CharProtDB: a database of experimentally characterized protein annotations. Nucleic Acids Res. 2011;40(D1):D237.

39. Barker WC, Garavelli JS, Huang H, McGarvey PB, Orcutt BC, Srinivasarao GY, et al. The Protein Information Resource (PIR). Nucleic Acids Res. 2000;28:41-4.

40. Crossman LC, Chen H, Cerdeño-Tárraga A-M, Brooks K, Quail MA, Pineiro SA, et al. A small predatory core genome in the divergent marine Bacteriovorax marinus SJ and the terrestrial Bdellovibrio bacteriovorus. ISME J. 2012;7:148-60.

41. Konstantinidis KT, Tiedje JM. Genomic insights that advance the species definition for prokaryotes. Proc Natl Acad Sci U S A. 2005;102:2567-72.

42. Konstantinidis K, Tiedje J. Towards a genome-based taxonomy for prokaryotes. J Bacteriol. 2005;187:6258.

43. Thompson C, Vicente A, Souza R, Vasconcelos A, Vesth T, Alves N, et al. Genomic taxonomy of vibrios. BMC Evol Biol. 2009;9:258.

44. Reichenbach H. The ecology of the myxobacteria. Environ Microbiol. 1999;1:15-21.

45. Lovley DR, Phillips E, Lonergan DJ, Widman PK. Fe (III) and $S^{0}$ reduction by Pelobacter carbinolicus. Appl Environ Microbiol. 1995;61:2132.

46. Karlin S, Brocchieri L, Mrázek J, Kaiser D. Distinguishing features of

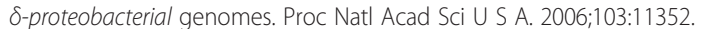

doi:10.1186/1944-3277-10-11

Cite this article as: Chen et al:: Draft genome sequences for the obligate bacterial predators Bacteriovorax spp. of four phylogenetic clusters. Standards in Genomic Sciences 2015 10:11. 